Dept. of Immunity,

Animal Health Research Institute, Mansoura Branch.

\title{
SOME BACTERIOLOGICAL AND SEROLOGICAL STUDIES ON ENTERITIS IN DUCKS
}

(With 4 Tables)

\begin{abstract}
By
A.M.E. ASAWY and M.M. ABD EL-LATIF*

* Dept. of Bacteriology, Animal Health Research Institute, Mansoura Branch.

(Received at 18/2/2010)

\section{بعض الدراسات البكتريولوجية والسيرولوجية على النزلات المعوية في البط \\ أبو الخي محد إبراهيم عيسوى ، محمود محمد محمود عبل اللطيف}

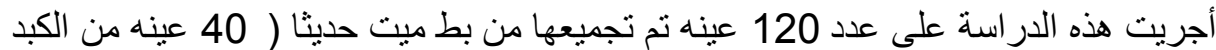

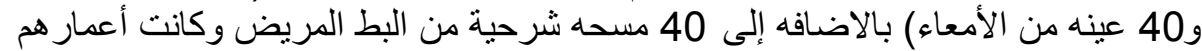

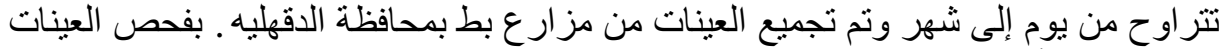

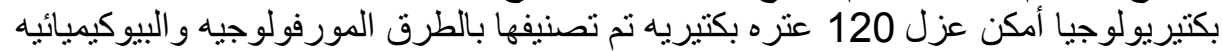

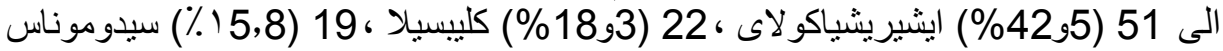

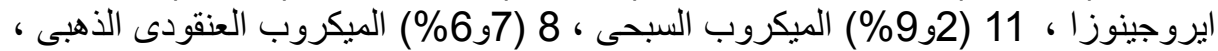

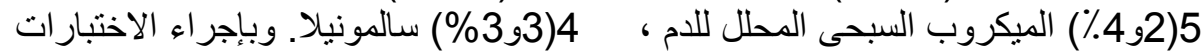

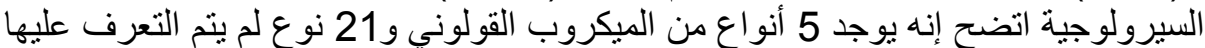

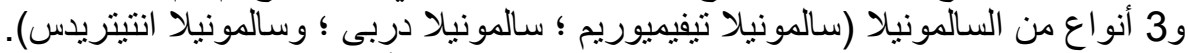

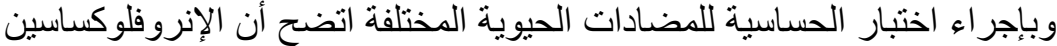

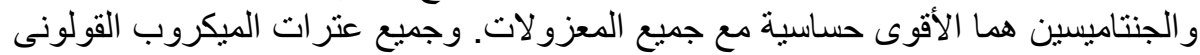
المعزولة من عينات البط تعطى سموم ممرضيه.
\end{abstract}

\section{SUMMARY}

A total of 120 samples from freshly dead ducks and 40 feacal samples from clinically sick ducks of different ages (1-30days) obtained from a private farms at the Dakahlia Governorate. The samples were dispatched to the laboratory to be examined bacteriologicaly for detection of actual bacterial causes of enteritis in ducks. All bacterial isolates were identified morphologically, culturally, biochemically and serologically for E.coli and Salmonella microorganisms. E.coli was the most prevalent bacterial agent 51(42.5\%) followed by Klebsiella spp. 22 (18.3\%), 
Pseudomonas aeruginosa 19(15.8\%), Strept. faecalis 11 (.9.2\%), Staph.aureus 8(6.7\%), B-haemolytic streptococci $5(4.2 \%)$ and Salmonella spp. 4(3.3\%). Serological identification of the isolated strains of E.coli from diarrhoeic duck showed that they belonged to 5 different "O" serogroups which were 26, 78, 86, 125, 157 and 21 strains of E.coli were serological untyped. Meanwhile, serotyping of the isolated strains of Salmonellae yielded 3 different serovars including S.typhimurium, S.derby and S.enteritidis. The antibiogram study done on all the isolated pathogens revealed that all strains were sensitive to Enerofloxacin and Gentamycin. All the isolated E.coli strains from the examined samples were enterotoxigenic produce heat labile enterotoxin.

Key words: Ducks, enteritis, bacteriological examination, antibiogram.

\section{INTRODUCTION}

Duck are however hardly and relatively resistant to most diseases, but are susceptible to a number of infectious agents acquired from and common to other avian species. Some of these agents may pose a threat to public health significance as well as viral and bacterial agents (Huchzermeyer, 1997). The researches have focused on enumerating the intestinal load of pathogenic bacteria such as Klebsiella spp., Staphylococci spp., Salmonellae, Escherichia coli and Arizonae spp. Salmonellae spp. and Escherichia coli are preponderant bacilli in the intestine of ducks (Cao et al., 2008). Infected ducks are listless, dehydrated, exhibit diarrhoea and show signs of incoordination and high mortality rate. The diseases condition are responsible for great economic losses in the poultry industry in many parts of the world (Brans and gross, 1997).

Like with, little information is available concerning the antibacterial resistance of common intestinal bacteria such as E-coli which isolated. Moreover, the manufacturing contaminated food, promotes recycle of Salmonellae into the meat production chain at farm level (Oosteram, 1991). Virulence factors associated with pathogenic E.coli of avain origin include the production of toxins (Dho-Moulin and Fairbrother, 1999).

The goal of this study was planned to identify and determine the incidence and types of aerobic, facultative anaerobic bacteria and serological identification of the isolated pathogens from digestive tract 
of diarrhoeic duck and determined their spectrum of antimicrobial activity. In addition to detect the enterotoxigenic strains of E.coli.

\section{MATERIALS and METHODS}

\section{Samples:}

A total of 120 samples were collected from dead and clinically sick ducks of different age (1-30 days) from a private farms at the Dakahlia Governorate. 80 samples collected from liver and intestine of freshly dead ducks as well as 40 from feacals swabs from clinically sick ducks.

\section{Bacteriological examination:}

Bacteriological samples were collected aseptically and each sample was divided into two parts. The first part was streaked onto predried surface of Boold agar, Nutrient agar, MacConkey agar (Oxoid, CM7) and Eosin methylene blue EMB Oxoid, CM6, incubated aerobically at $37^{\circ} \mathrm{C}$ for 24 hours. The second part was inoculated into Rappaport Vassiliadis broth RV (Oxoid CM 669) incubated at $42^{\circ} \mathrm{C}$, after 24 hours incubation, loopfulls from RV.enrichement were streacked onto Xylose lysine desoxycholate agar plate XLD (Oxoid,CM 469) with incubation at $37^{\circ} \mathrm{C}$ for 24 hours. The growing colonies on various plates were examined morphologically and biochemically according to Ksteman et al. (1996). The identified E. Coli strains were tested for enterotoxin production through grown the E.coli isolate in trypticase soya broth at $37^{\circ} \mathrm{C}$ in stationary culture overnight. Culture was centrifuged at $4000 \mathrm{rev} / \mathrm{min}$. For 20 minutes. The supernatant was tested using commercially VET-RPLA kits reversed passive Latex agglutination from Oxoid TD 0920A following the manufacturers direction.

\section{Serological identification:}

a- Antisera of E.coli were used for serological identification of somatic antigen "O" using slide agglutination test according to Edward and Ewing (1972).

b- Serological identification of the isolated strains of Salmonellae was performed according to Kauffman (1973) using slide agglutination for identification of somatic antigen while flagellar antigen was identified by tube agglutination test.

\section{Antibiogram pattern:}


Antibiogram was applied on the most of pathogenic isolated strains using in vitro disc diffusion technique according to Quinn et al. (1994) using Mueller Hinton agar plates. The results were interoperated according to Oxoid Manual company (Oxoid Manual, 2000).

\section{RESULTS}

\section{Clinical signs and P.M. lesions:}

The recorded clinical signs were diarrhoea, ataxia and off food. The p.M. examination revealed the presence of congestion in the internal organs (liver, spleen, intestine and enlarged gall bladder)

\section{Bacteriological examination:}

The results of bacteriological examination of 120 duck samples are given in Table (1). On the other hand, Table (2) shows the prevalence rate of various types of microorganisms isolated from samples and cloacal swabs of diseased duck. The most prevalent isolated bacteria were E.coli 42.5\%, Klebsiella spp. 18.3\%. Pseudomonas aeruginosa $15.8 \%$ followed by Strept faecalis $9.2 \%$ Staph aureus $6.7 \%$ B-haemolytic streptococci $4.2 \%$ and Salmonella spp 3.3\%.

\section{Serological identification:}

Serogrouping of 51 strains of E.coli isolated from diarrhoeic duck belonged to 5 different serogroups and 21 strains were untypable as illustrated in Table (3). Moreover, serotyping of 3 Salmonella isolates showed that they belonged to 3 different serovars including S.typhimurium, S.derby and S. enteritidis.

\section{Antibiogram pattern:}

Antibiogram of the most pathogenic microorganism were recorded in Table (4) showing that all tested strains were sensitive to Enrofloxacin, also with Gentamycin.

Table 1: Prevalence rate of bacterial pathogens isolated from diarrhoeic duck.

\begin{tabular}{|l|c|c|c|c|c|}
\hline \multirow{2}{*}{$\begin{array}{c}\text { Types of } \\
\text { Samples }\end{array}$} & \multirow{2}{*}{$\begin{array}{c}\text { No. of examined } \\
\text { samples }\end{array}$} & \multicolumn{2}{|c|}{ Positive samples } & \multirow{2}{*}{ Total } & $\%$ \\
\cline { 3 - 4 } & & Single & Mixed & & \\
\hline Liver & 40 & 12 & 26 & 38 & 95 \\
Faecal swabs & 40 & 22 & 12 & 34 & 85 \\
Intestine & 40 & 28 & 10 & 38 & 95 \\
\hline
\end{tabular}


Table 2: Prevalence rate of different microorganisms isolated from samples of diarrhoeic ducks

\begin{tabular}{|l|c|c|c|c|c|c|c|c|}
\hline \multicolumn{1}{|c|}{ Samples } & \multicolumn{2}{c|}{$\begin{array}{c}\text { Liver } \\
(38)^{*}\end{array}$} & $\begin{array}{c}\text { Faecal } \\
\text { Swabs(34)* }\end{array}$ & $\begin{array}{c}\text { Intestine } \\
(48)^{*}\end{array}$ & \multicolumn{2}{c|}{$\begin{array}{c}\text { Total } \\
(120)^{*}\end{array}$} \\
\hline & No & $\%$ & No & $\%$ & No & $\%$ & No & $\%$ \\
\hline E-coli & 13 & 34.2 & 16 & 47.1 & 22 & 45.8 & 51 & 42.5 \\
Staphylococcus aureus & 8 & 21.1 & - & - & - & - & 8 & 6.7 \\
B- haemolytic streptococci & 5 & 13.2 & - & - & - & - & 5 & 4.2 \\
Strep.feacalis & - & - & 4 & 11.8 & 7 & 14.6 & 11 & 9.2 \\
Salmonella spp. & 1 & 2.6 & - & - & 3 & 6.3 & 4 & 3.3 \\
Klebsiella spp. & 6 & 15.8 & 6 & 17.6 & 10 & 20.8 & 22 & 18.3 \\
Pseudomonas aeruginosa & 5 & 13.2 & 8 & 23.5 & 6 & 12.5 & 19 & 15.8 \\
\hline
\end{tabular}

*Percentage are calculated according to total number of isolates

Table 3: Serological identification of pathogenic strains isolated from diarrhoeic ducks.

\begin{tabular}{|c|c|c|l|c|c|}
\hline \multicolumn{3}{|c|}{ E.coli } & \multicolumn{1}{c|}{ Salmonellae } \\
\hline Serogroup & No & $\%$ & \multicolumn{1}{|c|}{ Serovar } & No & $\%$ \\
\hline $\mathrm{O}_{26}$ & 4 & 7.8 & S.typhimurium & 2 & 50.0 \\
$\mathrm{O}_{78}$ & 9 & 17.6 & S.derby & 1 & 25.0 \\
$\mathrm{O}_{86}$ & 5 & 9.8 & S.enteritidis & 1 & 25.0 \\
$\mathrm{O}_{125}$ & 6 & 11.8 & & & \\
$\mathrm{O}_{157}$ & 6 & 11.8 & & & \\
Untyped strains & 21 & 41.2 & & 4 & 100 \\
\hline Total & 51 & 100 & & &
\end{tabular}

Table 4: Antibiogram pattern of the pathogenic microorganisms isolated from diarrhoeic ducks.

\begin{tabular}{|c|c|c|c|c|c|c|c|}
\hline Tested pathogens & 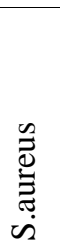 & 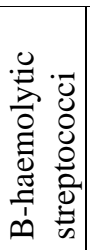 & 先 & $\begin{array}{l}\overline{0} \\
\overline{0} \\
\dot{0}\end{array}$ & $\begin{array}{l}\frac{\pi}{\bar{d}} \\
\frac{\vec{n}}{0} \\
\frac{0}{\Delta}\end{array}$ & 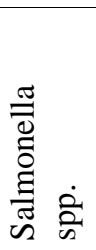 & 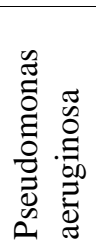 \\
\hline Enrofloxacin & SS & SS & SS & SS & SS & SS & SS \\
\hline Gentamicin & SS & SS & S & S & S & S & S \\
\hline Cefdroxil & S & $\mathrm{R}$ & $\mathrm{R}$ & $\mathrm{R}$ & $\mathrm{R}$ & $\mathrm{R}$ & $\mathrm{R}$ \\
\hline "200mg+250mg" & S & S & $\mathrm{R}$ & S & S & $\mathrm{R}$ & S \\
\hline Ciprofloxacin & SS & S & S & $\mathrm{R}$ & $\mathrm{R}$ & $\mathrm{R}$ & $S$ \\
\hline Colistin & $\mathrm{S}$ & $\mathrm{R}$ & $\mathrm{R}$ & S & $S$ & $\mathrm{R}$ & $\mathrm{R}$ \\
\hline Doxycycline & SS & $\mathrm{S}$ & S & $\mathrm{R}$ & $\mathrm{R}$ & $\mathrm{R}$ & $\mathrm{R}$ \\
\hline Erythromycin & $\mathrm{R}$ & S & $S$ & $\mathrm{R}$ & $\mathrm{R}$ & $\mathrm{R}$ & $\mathrm{R}$ \\
\hline $\begin{array}{l}\text { Trimethoprim + sulphamethoxazole } \\
\text { "1.25+23.75" }\end{array}$ & $\mathrm{S}$ & $\mathrm{R}$ & $\mathrm{R}$ & $\mathrm{R}$ & $\mathrm{R}$ & $\mathrm{R}$ & $\mathrm{R}$ \\
\hline Florfenicol & $\mathrm{S}$ & $S$ & $\mathrm{R}$ & SS & $\mathrm{R}$ & SS & S \\
\hline
\end{tabular}

$\mathrm{SS}=$ highly sensitive

$\mathrm{S}=$ sensitive

$\mathrm{R}=$ resistant 


\section{DISCUSSION}

Nowadays, a great attention was payed toward duck farms as a trial to fulfill excessive demand of increased population from the animal protein. The ducks meat are considered to be of high protein content with high biological value. Several microbial infection are responsible for enteritis in ducks.

In the present study, bacteriological examination of samples from diarrhoeic ducks as shown in Table (1) revealed that 95\% of liver, 95\% intestine and $85 \%$ of faecal swabs were positive for one or more known, these results agree to certain extent to those reported by Welsh et al. (1997) who isolated various types of microorganisms from internal organs of ostriches, and recorded mortality of 40-100\%. Various types of microorganisms have been isolated from examined samples as illustrated in Table (2). Those results are similar to those reported by Welsh et al. (1997) who isolated Staphyloccous spp. and S.aureus from ratite enteric samples. In the present study the most isolated organisms was E.coli $42.5 \%$. Similar result was reported by Clark (1996) who reported that E.coli was the main cause of enteritis in poultry. While Terzich and Vanhooser (1993) isolated E.coli in low percent from liver of dead duck. Also Farooq et al. (2009) isolated enteropathogenic E.coli (4.0\%) from duck. Moreover, Xingxiao et al. (2009) isolated E.coli (16.2\%) from duck suffering diarrhoea.

The rate of Salmonella isolates isolates as shown in Table (2) was $3.3 \%$ this results nearly coincide with those reported by Tsai and Hsiang (2005) who isolated Sal. spp. (4.6\%) from duck suffering diarrhoea. Meanwhile, Higgins et al. (1997) isolated one strain of Salmonella from the intestine of poultry, also Huchzermeyer (1997) isolated Salmonella from faecal swabs from ostrich. On the other hand, Gopo and Banda (1997) isolated Salmonella in higher percentage of 16.9 from the samples while $33.3 \%$ of the carcasses tested were positive of Salmonella they also mentioned that liver samples were negative for Salmonella.

In the present study the isolated Pseudomonas aeruginosa 15.8\%. On other hand, Safwat et al. (1984) who isolated Pseudomonas aeruginosa (15\%) from duckling suffering diarrhoea and high mortality. Moreover, Ibrahim et al. (2006) isolated Pseudomonas aeruginosa either a lone or with Staphylococcus and E.coli from different ages of chickens and ducklings. Jennes et al. (2000) who isolated P. aeruginosa from the intestinal tract of poultry. 
Serological identification of the isolated stains of E.coli revealed 5 different "O" serogroups which were "26, 78, 86, 125, 157 and 21 strains were untyped as shown in Table (3). Moreover Knoble et al. (2001) who isolated eight isolates of E.coli from ostriches and poultry carcasses and were serogrouped as 2,7,8,9, and 21.

In the present study, serotyping of the isolated strains of Salmonella revealed that "3" serovars S.typhimurium $(50.0 \%)$, S.derby $(25.0 \%)$ and S.enteritidis $(25.0 \%)$ were identified. On other hand Abd-EL Rahman and Mousa (2000) isolated S.typhimurum(12\%), S.enteritidis(5.6\%), and S.dublin(2.4\%) from ducks suffering enteritis. Vanhooser and Welsh (1995) who mentioned that S.typhimurium was the most prevalent serovar isolated from ratites. Jennes et al. (2000) mentioned that S.typhimurium was common in Multi-species collection and causes mortality in chicken younger than three months. Moreover Cadman et al. (1994) who detected antibodies of S.enteritidis in poultry in Zimbabwe. Also Tsai and Hsiang (2005) isolated S. derby and $S$. montevideo from ducks.

Table (4) showed that antibiogram pattern of the isolated pathogens from diarrhoeic duck revealed variable results against different therapeutic agents which had been used. The tested pathogens were sensitive to Enrofloxacin and Gentamycin. While variable results were recorded with the remaining antibiotics. The present results coincide with observation reported by Higgins et al. (1997) who mentioned that in antimicrobiol susceptibility testing of Salmonella isolated strains were sensitive to Enrofloxacin, Gentamycin and Ampicillin, also Simpraga et al. (2005) recorded that S. typhimurium isolated from duck was sensitive to Enrofloxacin. In addition. Bastawrows (1997) found that $P$. aeruginosa isolated strains were sensitive to Gentamycin and Polymyxin B. Meanwhile, Summano et al. (1998) reported that Enrofloxacin was effective in treatment of natural infection of E.coli. Moreover, Galland et al. (2001) recorded that E-coli 0157:H7 was susceptible to Ciprofloxacin and Enrofloxacin.Futhermore Welsh et al. (1997) who reported that Enrofloxacin would be the drug of choice in treatment of Gram.negative bacterial infection in poultry while Amoxicillin would be a good choice for the most Gram-positive bacterial.

Contrary to these results, it was reported by Higgins et al. (1997) who mentioned that the isolated strains of Salmonella were sensitive to Tetracycline and Trimethoprim+ sulfamethoxazole. 
In this study, all the isolated E.coli strains from examined samples were enterotoxigenic produce heat labile enterotoxin when tested by VET-RPLA kits, and serologically identified as $7.8 \%$ E.coli $\mathrm{O}_{26}, 17.6 \%$ E.coli $\mathrm{O}_{78}, 9.8 \%$ E.coli $\mathrm{O}_{86}, 11.8 \%$ E.coli $\mathrm{O}_{125}, 11.8 \%$ E.coli $\mathrm{O}_{157}$ and $41.2 \%$ untypable strains (Table 3). Many investigators studied the toxigenicity of E.coli isolated from different species of diarrhoeic animal and poultry. The present study nearly coincide with observation of Joya et al. (1990) who isolated 42 strains of E-coli in diarrhoeic broiler chicks, they reported that 3 strains were enterotoxigenic by suckling mouse assay. Meanwhile, Wolk et al. (1992) found that the main enterotoxigenic strains belonged to serogroup; 10,9,8,90 and 56 . Heekon (1999) in Korea reported that the most prevalent strains of E.coli were 20, also he mentioned that in Australia the most common "O" group currently encountered were 9,20 and 101,while 111,119 and 125 elaborated enterotoxin. Otherwise, our results were in contrast with these reported by Jorge et al. (1988) who isolated 73 E-coli strains from broiler and found that the isolated strains did not produce enterotoxin.

In conclusion, the information given by the achieved results revealed that several microorganisms were incriminated in the enteritis in ducks and E.coli is the most perevalent which treated by using Enrofloxacin beside strict hygienic measurements on the egg laying, hatcheries and good management during the production.

\section{REFERENCES}

Abd-EL Rahman, A.M. and Mousa, H.M.M. (2000): Bacteriological and Histopathological studies on Salmonella isolates from ducks in North Sinai. Egypt. J. Agric. Res. 78 (1): 15-23.

Bastawrows, A.F. (1997): Occurrance and significance of Pseudomonas aeruginosa in some meat product. Assiut Vet. Med. J., 37: 86-99.

Brans, l.H. and Gross, W.B. (1997): Colibacillosis. In calnek. B.w., branes J.h., beard c.w. mac dougold, r.l., saif y.m. (eds) disease of poultry, lowa state university press Ames, lowa pp. 131-141.

Cadman, H.F.; Kelly, P.J.; Zhou, R.; Davelaar, F. and Mason, P.R. (1994): A serosurvey using enzyme linked Immunosorbent assay for antibodies against poultry pathogens. Avian Dis., 36: 621-625. 
Cao, S.Y.; Wang, M.S.; Chang, A.C.; Oi, X.F.; Yang, X.Y.; Deng, S.X.; Yin, N.C.; Zhang, Z.H.; Zhou, D.C.; Zhu, D.K. and Luo, Q.H. (2008): Comparative analysis of intestinal microbial community diversity between healthy and orally infected duckling with Salmonella enteritidis by ERIC-PCR. World Gatroenterol, 14(7) 1120-1125.

Clark, F.D. (1996): Necropsy finings in "70cases" Agri. Practice, 17: 34-35.

Dho-Moulin, M. and Fairbother, J.M. (1999): Avian pathogenic E.coli "APEC" Vet. Res., 30: 299-316.

Edward, S.P.R. and Ewing, W.H. (1972): Identification of enterobacteriaceae, $3^{\text {rd }}$ ed Burgess publishing Co. Minncapolis.

Farooq, S.; Hussain, 1.; Mir, M.A.; Bhat, M.A. and Wani, S.A. (2009): Isolation of atypical enteropathogenic E.coli and shigatoxin 1 and $2 \mathrm{~F}$ producing E.coli from avian species in India. Applied Microbiology 48, 6: 692-697.

Galland, J.C.; Hyatt, D.R.; Crupper, S.S. and Acheson, D.W. (2001): Prevalence, antibiotic susceptibility and diversity of E.coli 0157:H7 isolated from longitudinal study of beef cattle feedlots. Appl. Enviro. Microbiol., 67: 1619-1627.

Gopo, J.M. and Banda, G.N. (1997): Occurrance of Salmonella on meat and products in an abattoir as determined with a DNA probe. S.Afr. Anim.Sci., 27: 1-6.

Heekon, J.K. (1999): Identification of serotype by use of serologic assay and detection of enterotoxin gene of E-coli by means of a polymerase chain reaction assay isolated from pigs, chickens and cows. Am. J. Vet. Res., 60: 468-472.

Higgins, R.; Desilets, A.; Contin, M.; Messier, S.; Khakhria, R.; Ismail, J.; Mulvey, M.; Daignaut, D. and Caron, H. (1997): Outbreak of Salmonella give in the province of Quebeccau.Vet. J., 38: 780-781.

Huchzermeyer, F.W. (1997): Public health risks of ostrich and crocodile meat. Rev.Sci. Teach. Off. Int. Ep. iz. 16: 599-604.

Ibrahim A. Ghanem; Amal A.M. Eid; Nasser A. Elsayed and Eman A. Rashed (2006): Pseudomonas infection among chickens and ducklings. Zag. Vet. J. (ISSN.1110-1458) Vol. 34, No. 1. PP. 84-93.

Jennes, W.; Dicks, L.M.T. and Verwoerd, D.J. (2000): Enterocin 012, a bacteriocin produced by Enterococcus gallinarum isolated from the intestinal tract of ostrich. J. Appl. Microbiol., 88: 349-357. 
Jorge, M.A.; Silva, E.V.; Castro, A.F. and Olive (1988): Some Serological and Bacteriological studied on Enteritis pathogenicity factors in E-coli isolated from chickens. ArquroBrasileir. Mer. Vet. Zoo tecnia, 40: 35-48.

Joya, J.E.; Tssuii, T.; Jacalne, A.V.; Atra, M.; Tuskamoto, T.T.; Honda,

T. and Miwatant, T. (1990): Demonstration of enterotoxigenic

E.coli in diarrhoeic broiler chickens. Euro. J. Epid., 6: 88-90.

Kauffman, F. (1973): Serological diagnosis of Salmonella spp. Kaufkauffmann white scheme, Copenhagen, Denmark.

Knoble, T.; Baccaro, M.R.; Moreno, A.M.; Gomes, T.A.T.; Vieria, M.A.M.; Ferreria, C.S.A.; Antonio, J. and Ferreria, P. (2001): Virulence properties of E.coli isolated from ostriches with respiratory disease. Vet. Microbiol., 83: 71-81.

Ksteman, E.W.; Allen, S.D.; Janda, W.M.; Schrecheneberger, P.C. and Winn, W.C. (1996): Introduction to diagnostic. $6^{\text {th }}$ ed. Lippinestt Company, Philadelphia USA.

Oostteram, J. (1991): Epidemiological studies and proposed preventive measurees in the fight against human salmonellosis Int. J. Food Microbiol., 12: 41-51.

Oxoid Manual (2000): The oxoid manual o culture media ingredients and other laboratory services. Loth Ed., published by oxoid limited wade Road Basingstocke, Hampshire, England.

Quinn, P.J.; Carter, M.E.; Markery, B.K. and Carter, G.R. (1994): clinical Vet. Microbiology. Wolf published. Europe limited.

Safwat, E.E.A.; Awaad, M.H.; Ammer, A.M. and El-Kinawy, A.A. (1984): Studies on Pseudomonas aeruginosa, Proteus vulgaris and S.typhimurium infection in duckling. Egypt. J. Anim. Prod. 24: 287-294.

Simpraga, B.; Tisljar, M.; Krstulovic, F. and Sokolovic, M. (2005): Hafnia alvei and Salmonella typhimurium infection in the duck. VI. Simpozij Peradarskidani. Meunarodnim sudjelovanjem, Hivatska, Porec, 11-14.

Summano, L.H.; Ocampo, C.L.; Brumbough, G.W. and Lizarrage, (1998): Effectiveness of two fluoroquinolones for the treatment of chronic respiratory disease outbreak in broilers. Brit poult. Sci, 39: 42-46.

Terzich, M. and Vanhooser, S. (1993): Postmortem finding of avain submitted to the Oklahoma Animal Disease Diagnostic Laboratory. Avain Dis., 37: 1136-1141. 
Tsai, H.J. and Hsiang, P.H. (2005): The prevalence and antimicrobial susceptibilities of Salmonella and Campylobacter in duck in Taiwan. J. Vet. Med. Sci. 67: 7-13.

Vanhooser, S.L. and Welsh, R.D. (1995): Isolated of Salmonella spp. from ratites. J. Vet. Diag. Invest., 7: 268-269.

Welsh, R.D.; Roger, W.; Nieman, B.S.; Staly, L.; Vanhooser, Laura B. and B.A. (1997): Bacterial infection in ratites.Vet. Med., 11: 992-998.

Wolk, M.; Ohad, E.; Shpak, B.; Adler, H. and Nohari, N. (1992): A survey of studies on enteritis in broiler J.Vet. Diag. Invest., 8: 86-90.

Xingxiao, Z.; Shijin, J.; Jiaqiang, W.; Qin, Z.; Yani, S.; Yibo, K.; Xiaoxia, L.; Meiling, Y. and Tongjie, C. (2009): An investigation of duck circovirus and co-infection in chery valley ducks in Shnadong province, China. Vet. Microb. 133, 3: 252-256. 